\title{
Trace Minerals, Physicochemical and Phytochemical Composition of Locally Prepared Beverages (Kunu and Sobo) Commonly Consumed by Tertiary Institution Students in Ekiti State, Nigeria
}

\author{
Ojo Olabimpe Iyabo ${ }^{1}$, Oyarekua Mojisola O. ${ }^{2}$, Jegede Rufus Olufemi ${ }^{1}$ \\ ${ }^{1}$ Department of Chemistry, College of Education, Ikere-Ekiti, Nigeria \\ ${ }^{2}$ The Provost, College of Education, Ikere-Ekiti, Nigeria \\ Correspondence: Ojo Olabimpe Iyabo, Department of Chemistry, College of Education, Ikere-Ekiti, Nigeria.
}

Received: January 11, 2018 Accepted: April 23, 2018 Online Published: April 27, 2018

doi:10.5539/ijc.v10n2p80

URL: https://doi.org/10.5539/ijc.v10n2p80

\begin{abstract}
Trace minerals, physicochemical and phytochemical composition were determined in locally prepared kunu and sobo commonly consumed by students of tertiary institutions in Ekiti State. Determination of $\mathrm{pH}$ and total solid was achieved by official method prescribed by Association of Analytical Chemists (AOAC). Trace minerals were determined by flame atomic absorption spectrometry (FAAS) while determination of vitamin C was achieved by oxidation-reduction methods using standard 2,6- Dichloro indo phenol (DCP). Result revealed that $\mathrm{pH}$ of the samples ranged from 5.26 in sobo to 6.02 in kunu with an average value of 5.64. Total solid ranged from $0.62 \%$ in sobo to $7.25 \%$ in kunu. Toxic minerals concentrations of $\mathrm{Ni}, \mathrm{Pb}$ and $\mathrm{Cd}$ with values $0.14,0.19$ and 0.05 respectively were observed in sobo while 0.13 , 0.01 and 0.04 were observed in kunu, all in parts per million respectively. All the values were within the permissible limits as set by FAO/WHO guidelines for food standard. Co and $\mathrm{Cr}$ were not detected in them. Vitamin $\mathrm{C}$ contents for sobo and kunu are 5.26 and 6.02 all in mg 100g respectively. The result when compared with the USDA (SR21) database shows that the two samples studied provided less adequate vitamin $\mathrm{C}$ content than their natural counterpart, but could serve as anticarcinogenic and antimuitagenic agents for human due to the presence of phytochemicals like phenolics, tannin and flavonoids in them.
\end{abstract}

Keywords: trace minerals, physicochemical and phytochemical, beverages, Nigeria

\section{Introduction}

The consumption of locally prepared herbal soft drinks (Kunu and Zobo) is gaining prominence due to financial economic crisis especially in Ekiti State, Nigeria.

The recession in the economy has caused majority of the populace especially the students in Ekiti State to look for alternative and affordable herbal natural drinks which is less costly and are reported to have potential health benefits than that of the imported refined drinks like Coca kola and Maltina drinks.

KUNU which is also known as kunu-zaki is the traditional Hausa name of a non-alcoholic beverage which is widely consumed in Nigeria. It's a major source of calories and supplied large proportion of energy in form of carbohydrates. Kunu is taken as an alternative to imported beverage and is mostly consumed throughout Nigeria, mostly in the North (Ikpoh et al, 2013). Kunu is of low viscosity and have a sweet sour taste, milky cream in appearance and is consumed on its own by adult as a thirst quencher or serve as refreshment in some communities (Adeyemi and Umar, 1994). Kunu drink is relatively cheap due to the availability of its constituent materials. It is made from cereal grains such as maize (Zea mays), millet (pennisetumtyphoideumi) and sorghum (vulgare). (Akorna et al 2002) Garlic, pepper and ginger are some other ingredients which are added to enhance its flavour, while honey or sugar is also added to serve as sweetener (Gaffa et al, 2002).

Kunu drink is also known to help in reducing the risk associated with diabetes. The key ingredient, millet, called polynutrient has lignam, which has cancer fighting properties and is beneficial in the treatment of heart disease. It is also good for the relaxation of the muscles of menopausal women. It contains fibre, thus helping to promote a healthy digestive system and help in the prevention of chronic inflammatory diseases such as rheumatoid arthritis.

\section{SOBO (Hibiscus Tea)}

Zobo has a unique taste that makes it acceptable to all classes of people. In Nigeria and Senegal, (West Africa) it is a 
sharp tasting herbal infusion taken as tea and juice. The flower is also used in making juice, wine, tea and spices. It can also be used in making raw salad. Roselle is neither a fruit nor flower it's easy to mistake, Roselle for a juice in tropical countries because it's commonly sold by the street side and in food courts alongside with fresh pineapple, orange, lemon and coconut juices. Roselle (Hibiscus) has been used in folk medicine as a diuretic and milk laxative, as well as in treating cancer and cardiac diseases. The potential for hibiscus use in treating hypertension and cancer is highly encouraging.

Hibiscus tea (Zobo) can be drunk hot or cold. As iced tea, the infusion is known to satiate thirst quite effectively. It is often recommended as an alternative to artificially made commercial "sport drinks" that are marketed. Health benefit of hibiscus is probably associated with its diuretic properties. which help against high blood pressure. It also helps treat cold and cough, zobo drink helps in weight loss.

Previously, proximate composition and essential mineral contents in different locally prepared herbal drinks has been the subject of many studies in developing countries such as Nigeria where food composition data are primarily on proximate composition and other nutrients. Recently, the few data from previous studies on the assessments of phytochemical and physicochemical parameters of food items commonly consumed in Nigeria, especially in Ekiti State were focused on vegetables, medical plants and citrus fruits consumed generally by the populace while less attention has been paid to locally prepared beverages commonly consumed by the people, most especially the students within higher institution campuses.

However the incidence of drinks related diseases is becoming rampant among the Tertiary Institution Students in Ekiti State. Hence, this study was designed to determine the concentration of some selected trace metals as well as phytochemical and some physiochemical parameters of the two commonly consumed natural locally prepared herbal drinks (Kunu and Zobo) by the College of Education students in Ekiti State.

\section{Materials and method}

\subsection{Sampling and Sampling Record}

Using College of Education as a case study, base on the nutritional importance of this study, questionnaire was designed, validated and used as an instrument to find out from 500 consenting students within the campus, the herbal drinks or beverages commonly consumed by them. The coefficient of the reliability of the instrument was found to be 0.76 by using crombach Alpha, after the distribution and collection of the questionnaires.

\subsection{Sample Collection}

The drink samples (kunu and sobo) commonly consumed by the students as indicated in the questionnaire filled by the respondents were collected directly from the drink vendors within the campus.

\subsection{Determination of Trace Mineral Content}

Ten grams of kunu was weighed into a conical flask containing $5 \mathrm{ml}$ of nitric acid and $10 \mathrm{ml}$ of hydrochloric acid and boiled on a hot plate until the solution was cleared. The mixture was allowed to cool down and was transferred into $100 \mathrm{dm} 3$ volumetric flask and made up to the mark with distilled water. Metal contents of $\mathrm{NI}, \mathrm{Pb}, \mathrm{Cd}, \mathrm{Co}$ ad $\mathrm{Cr}$ were analyzed using Flame Atomic Absorption Spectrometry (FAAS-Bck 210 VGP Model)

\subsection{Physichochemical Parameters}

\section{pH Determination:}

About $25 \mathrm{ml}$ of kunu drinks was mixed with $100 \mathrm{ml}$ of distilled water in a $500 \mathrm{ml}$ beaker and was thoroughly shaken and thereafter, left to stand for 20 minutes before it was filtered and filtrate was used for $\mathrm{pH}$ determination using $\mathrm{pH}$ meter (3305, Jenway model)

\section{Total solid determination:}

$5 \mathrm{~g}$ of kunu drinks was weighed into a flat-bottom flask and heated for 1 hour until the liquid evaporated leaving behind the solid. This was immediately transferred into an oven set at $100^{\circ} \mathrm{C}$ for 2 hours and re-weighed. The content was cooled and weighed. The process was done severally until a constant weight was obtained according to the method described by AOAC (2002).

\section{Vitamin C Content Determination}

Oxidation-reduction titration method describe by AOAC (1990) was used in determination of vitamin C content of the PJ. Five millilitres of each PJ, was treated with $10 \mathrm{ml}$, 3\% metaphosphoric acid and filtered to remove possible protein interference. The filtrate was then titrated against freshly standardization was with $10 \mathrm{ml}$ of standard ascorbic acid (Oxymin, Krpan Queensland). Triplicate titration was conducted for all samples. 


\section{Phytochemical analysis}

Quantitative determination of the phytochemical constituents of the local beverages was done using gravimetric method with some modification, Okereke et al., (2015). The determination was carried out on alkaloid, flavonoid, phenols saponins tannins and glycosides. The percentage constituent was calculated thus;

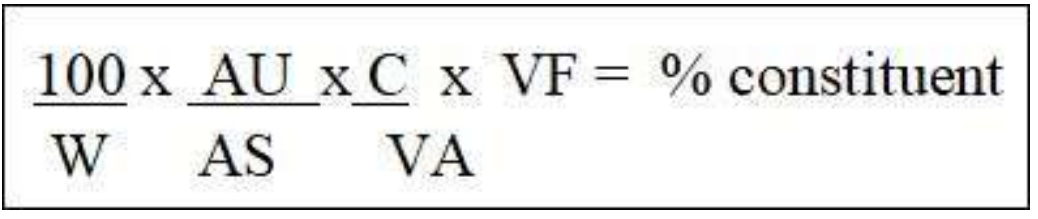

Where:

$\mathrm{W}=$ Weight of sample analyzed

$\mathrm{AU}=$ Absorbance of test sample

$\mathrm{AS}=$ Absorbance or concentration of standard solution

$\mathrm{VF}=$ Total volume of filtrate analyzed

$\mathrm{VA}=$ Volume of filtrate analyzed

$\mathrm{C}=$ Total volume of extract.

Results and discussion

Trace Mineral Analysis

The results obtained for the trace mineral content analysis of kunu and sobo drinks commonly produced and consumed by the students in Ekiti State are shown in Table 1. The results showed that the concentration (ppm) of $\mathrm{Ni}, \mathrm{Pb}$ and $\mathrm{Cd}$ in kunu and sobo were found to range from 0.13 to $0.14,0.01$ to 0.19 and 0.04 to 0.05 respectively. Co and $\mathrm{Cr}$ were not detected in the two samples. Minerals are nutritionally important components of food or drink and they could be classified as essential or non essential elements. However, there exists. Mineral safety index over which the supplies of mineral elements become toxic. Above and below this range (safe limit), toxic and deficiency effects are observed respectively (Merian, 1991). As a result of this, it is imperative to establish mineral contents of food or drink items in living organisms.. Metals such as Lead and Cadmium are toxic metal that have no known vital or beneficial effect on organism, and their accumulation over time in the bodies of human can cause serious illness (WHO, 2007). Generally speaking, these toxic metals disrupt functions in vital organs and glands such as the heart, brain, kidney bone and liver. They also displace vital nutritional minerals from where they should be in the body to provide biological functions. Mineral elements can influence behaviour in human by impairing immune, mental and neurological function. Influence neurotransmitter production and utilization and altering the metabolic process in the body. (WHO, 2007) Nickel from sobo drinks has the highest value of $0.14 \mathrm{ppm}$ for the essential minerals. Also for the toxic minerals $(\mathrm{Pb})$, the highest value $(0.19 \mathrm{ppm})$ was also found in zobo. Zobo has the highest value of nickel (0.14), Lead (0.19) and Cadmium (0.05) all in $\mathrm{mg} / \mathrm{kg}$.

\section{Vitamin C Contents}

The result of Vitamin C concentration is shown in Table 2, the concentration ranged from $8.04 \mathrm{mg} / 100 \mathrm{ml}$ in Kunu to $10.14 \mathrm{mg} / 100 \mathrm{ml}$ in sobo drink. The vitamin C content recorded in this study are generally lower than the USDA(SR21) database, but similar to that reported by Kabasakalis (2000), in which ascorbic acid content of commercial plant juice ranged from 2.4 to $4.3 \mathrm{mg} / 400 \mathrm{ml}$ of juice. Vitamin $\mathrm{C}$ helps in the preservation of natural colour and flavour of plant drinks or juice. It also adds nutritive value as well (Harrison and Andress, 2004).

\section{pH and Total solid Contents}

The $\mathrm{pH}$ values obtained for Kunu and sobo analysed in this present research work shown in Table 2 indicated that they are all acidic. The $\mathrm{pH}$ values range between 5.26 in sobo to 6.02 in kunu. These values are similar to the range of 5.25 to 5.65 reported by Amusa and Ashaye (2009) in a similar work on Kunu drinks.

Analysis of the total solid showed in table 2 that sobo and Kunu contain 0.62 and $7.25 \%$ respectively. Kunu contain higher amount of total solid and this might be due to residue from cereals (Sorghum and millet) seeds.

\section{Phytochemical Contents}

Evaluation of both sobo and kunu drinks demonstrates that both samples contain phytoconstituents like Flavonoid, Alkanoid, Phytate, Tannin, Saponin, Phenolic and Anthraquinones. Phytochemical concentrations for sobo and kunu were reported in Table 3. The results showed that the concentration of Flavonoid, Alkanoids, Phytate, Tannin, Saponin, 
Phenolic and Anthraquinones were found to range from 3.14 to $3.51,0.18$ to $0.20,9.14$ to $12.64,0.54$ to $0.63,0.64$ to $0.76,43.2$ to 92.4 and 0.001 to 0.002 respectively.

Phytochemicals are non-nutritive naturally occurring plant chemicals which provide plant with colour odour and flavour (Prior, 2005). They are not required by human body for sustaining life, but recent research demonstrates that they can also protect human against diseases despite the fact that they are well known that they are produce by plant to protect themselves. (Hertog et al., 1995).

Tannins from an insoluble product with protein which has a damaging effect on the liver medically was found in both sobo and kunu at a very low concentration. Tannin when in high concentration can inhibit the absorption of some essential minerals.

Saponin, which are also toxic and could even injure the surface membrane of leucocytes and liberates enzymes such as alkaline phosphate from damaged cells are also found in the samples at very low concentration.

Alkanoids, though poisonous which have physiological effects that render them valuable as medicines and also acts as local anesthetics, painkiller and probiotics used in pediatric medicine for babies and young children, with also benefits of improving gastrointestinal health were also reported to be found in the samples at a very low concentration.

Flavonoids, which are the most diverse group of phytochemicals that contribute to the reduced mortality rates as observed in people consuming high level of plant based food. (Hertog, et al 1993) were also present in drink samples.

Phenolic, were found in drinks samples and it has antimutagenic effects since they act as protective agents of DNA against the free radicals, by inactivating carcinogens inhibiting enzyme involves in pro-carcinogen activation and by activating of xenobioties detoxification enzymes.

Table 1. Minerals Analysis

\begin{tabular}{lllllll}
\hline S/No & Sample Codes & Ni & Cr & Pb & Cd & Co \\
\hline 1 & KUNNU & 0.13 & ND & 0.01 & 0.04 & ND \\
2 & SOBO & 0.14 & ND & 0.19 & 0.05 & ND \\
\hline
\end{tabular}

Table 2. Physicochemical Analysis

\begin{tabular}{|c|c|c|c|c|}
\hline S/No & & pH & Total Solids \% & VITAMIN C mg/100g \\
\hline 1 & KUNU & 6.02 & 7.25 & 8.04 \\
\hline 2 & SOBO & 5.26 & 0.62 & 10.14 \\
\hline
\end{tabular}

Table 3. Phytochemicals Analysis

\begin{tabular}{llllllll}
\hline & Flavonoid & Alkaloid & Phytate & Tannin & Saponin & Phenolic & Anthraquinone \\
\hline Samples & \% & $\mathbf{m g / 1 0 0 g}$ & $\mathbf{m g} / \mathbf{1 0 0 g}$ & $\mathbf{m g} / \mathbf{1 0 0 g}$ & $\mathbf{\%}$ & $\mathbf{m g} / \mathbf{1 0 0 g}$ & $\mathbf{m g} / \mathbf{1 0 0 g}$ \\
KUNU & 3.14 & 0.20 & 12.6 & 0.63 & 0.76 & 43.2 & 0.002 \\
SOBO & 3.51 & 0.18 & 9.14 & 0.54 & 0.64 & 92.4 & 0.001 \\
\hline
\end{tabular}

\section{Conclusion}

In this study, kunu and sobo drinks commonly consumed by the tertiary institutions in Ekiti State were found to contain toxic minerals $\mathrm{Pd}$ and $\mathrm{Cd}$ at concentration within the safe limit (FAO, 2011). The $\mathrm{pH}$ for both drink samples revealed moderate acidity which suggests that they are of good nutritive value.

Vitamin $\mathrm{C}$ which is effective in preventing discolouration in the drinks and also adds to its nutritive value as well (Harrison and Andress, 2004) were present at a very low level based on the USDA (SR21) which may not provide the daily value $(60 \mathrm{mg})$ for vitamin $\mathrm{C}$.

\section{References}

Adebayo, G. B., Otunola, G. A., \& Ajao, T. A. (2010). Physicochemical, microbiological and sensory characteristics of kunu prepared from millet, maize and guinea corn and stored at selected temperature. Adv. J. Food Sci. and Techno., 2(1), 41-46.

Adeyemi, I. A., \& Umar, S. (1994). Effect of Method of Manufacture on Quality Characteristics of Kunu Zaki, a Milletbased Beverage, Nigerian Food Journal, 12, 34-41.

Akomam V., Onuoha, S. A., Ajiboye, M. O., Akomaland A. O., \& Alawoki, A. M. (2002). The Nutritional and Sensory Quality Characteristics of Kunun-Zaki Produced with the Addition of Hydrolytic Enzymes from Malted Rice (Oryza saliva), Journal of Food Technology in Africa, 7(1), 24-26.

Allesio, L. (1992). Reference values for study of low doses. The sciences of the total Environ., 120(1-2), 1-6. https://doi.org/10.1016/0048-9697(92)90211-A 
Ameriacan Association of Cereal Chemists International (AACC). Whole Grain Task Force and Definition. 2009. Available online: http//www.aaccnet.org/definition/wholegrain.asp (accessed on 17 March 2014).

Amusa, N. A., \& Ashaye, O. A. (2010). Effects of processing on nutritional, microbiological and sensory properties of kunu-zaki (A sorghum based non-alcoholic beverage) widely consumed in Nigeria. Par. J. Nutr., 8(3), 288-292.

AOAC. (1990). Official methods of analysis (15th ion), Association of Official Analytical h mists, Washington D.C. 808-834.

AOAC. (1990). Official Methods of Analysis. Association of Analytical Chemists, Washington DC.

AOAC. (2002). Official Methods of Analysis. Association of Analytical Chemists, Washington DC.

FAO (2011). Food outlook; global market analysis. June issue, 1-112.

Gaffa, T., Jideanil, A., \& Nkema, I. (2010). Traditional production, consumption and storage of kunu-a non-alcoholic cereal beverage. plant food for human consumption. African Journal of Food Science, 57(1), 73- 81.

Harrison, J. A., \& Andress, E. L. (2004). Preserving food. freezing fruits. Technical Report V of The University of Georgia College of Agricultural and

Hertog, M. G., et al., (1993). Dietary ..9JJtioxidant fiavonoids and risk of coronary heart disease: the Zutphen Elderly Study. Lancet., 312(8878), 1007-1011.

Hertog, M. G., Feskens, E. J. M., Kromhout, D., Hollman, P. C. H., \& Katan, M. B. (1990). Dietary antioxidant flavonoids and risk of coronary heart disease: the Zutphen E.lderly Study. Lancet, 342(8878), 1007-1011. https://doi.org/10.1016/0140-6736(93)92876-U

Hertog. M. G., Daan, K., \& Christ, A. (1995). Flavonoid intake and long-term risk of coronary heart disease and cancer in the seven countries study. Arch. Intern. Med., 155(4), 381-386. https://doi.org/10.1001/archinte.1995.00430040053006

Ikpoh, I. S., Lennox, J. A., Ekpol, A., Agbo, B. E., l' Henshew, E. E., \& Udoekong, N. S. (2013). Mircrobial quality assessment of kunu beverage locally prepared and hawked in Calabar, Cross River State, Nigeria. Journal of Current Research in Science, 1(1), 20-23.

Kabasakalis, Y., Siopidou, D., \& Moshatou, E. (2000). Ascorbic acid content of commercial V fruit juices and its rate of loss upon storage. Food Chemistry, 70(3), 325-328. https://doi.org/10.1016/S0308-8146(00)00093-5

Merian, E. (1991). Metals and their compounds in the environment (VCH, New York), 3-17.

Prior, I., \& Gu, L. (2005). Occurrence and biological significance proanthocy nadins in American diet. Pyhtochemical. 66, 2264-2280. https://doi.org/10.1016/j.phytochem.2005.03.025

\section{Copyrights}

Copyright for this article is retained by the author(s), with first publication rights granted to the journal.

This is an open-access article distributed under the terms and conditions of the Creative Commons Attribution license (http://creativecommons.org/licenses/by/4.0/). 